Jurnal Viabel Pertanian Vol. 12 No.2 November 2018 p-ISSN: 1978-5259 e-ISSN: 2527-3345

Copyright@UNISBA Blitar , http://viabel.unisbablitar.ejournal.web.id

Wirianti Masitoh, Palupi Puspitorini \& Jeka Widiatmanta, 2018. Pengaruh Dosis Pupuk Bioslurry Cair dan Jarak Tanam Terhadap Pertumbuhan dan Hasil Tanaman Mentimun (Cucumis sativus L.). Journal Viabel Pertanian. (2018), 12 (24) - 32-39

\title{
PENGARUH DOSIS PUPUK BIO SLURRY CAIR DAN JARAK TANAM TERHADAP PERTUMBUHAN DAN HASIL TANAMAN MENTIMUN (Cucumis sativus L.)
}

\author{
Wirianti Masitoh $^{-1}$, Palupi Puspitorini ${ }^{-2}$, Jeka Widiatmanta ${ }^{-2}$
}

1. Mahasiswa Program Studi Agroteknologi Fakultas Pertanian, Universitas Islam Balitar, Blitar

2. Dosen Program Studi Agroteknologi Fakultas Pertanian, Universitas Islam Balitar, Blitar

\begin{abstract}
ABSTRAK
This study aims to determine the effect of liquid organic fertilizer on the growth and yield of cucumber plants, to determine the effect of applying spacing on the growth and yield of cucumber plants, to determine the interaction of liquid bio slurry fertilizer and spacing on growth and yield of cucumber plants. The study was conducted using a randomized block design arranged in factorial (RAK) with 2 factors, the first factor was a liquid bio slurry fertilizer $(P)$ dose consisting of 3 levels, $40 \mathrm{l} / \mathrm{ha}-1$ (P1), $80 \mathrm{l} / \mathrm{ha}-1$ (P2), $120 \mathrm{l} / \mathrm{ha}-1$ (P3). The second factor is the spacing (J) consisting of 3 levels: $30 \times 60 \mathrm{~cm}(J 1), 40 \times 60 \mathrm{~cm}(J 2), 50 \times 60 \mathrm{~cm}(J 3), 60 \times 60 \mathrm{~cm}$ (J4). The variables observed included stem diameter, leaf area, and total weight. Data were analyzed using analysis of variance (ANOVA) level of 5\% and further testing with Duncan 's Multiple Range Test (DMRT). The results showed: By giving different liquid slurry bio fertilizer doses gave a significant effect on the leaf area of cucumber plants at the age of 21 HST observations. The best treatment for organic fertilizer dosage is in the treatment of $120 \mathrm{~L} \mathrm{ha}-1$ (P3). The application of spacing has a significant effect on the stem diameter variable at the age of 28 HST observations, and on leaf area variables at all ages of observation. The best treatment of spacing on the variable stem diameter and leaf area on the treatment spacing of $60 x 60 \mathrm{~cm}$ (J4). There were no significant interactions on the treatment of liquid bio slurry fertilizer doses and the spacing of growth and yield of cucumber plants at all ages of observation.
\end{abstract}

Keywords: Planting Distance, Liquid Bio Slurry Fertilizer, Cucumber.

\section{PENDAHULUAN}

Mentimun (Cucumis sativus L.) termasuk dalam suku labu-labuan atau Cucurbitaceae merupakan tumbuhan buah yang dapat dimakan ketika belum masak atau dijadikan sayuran. Manfaat buah mentimun bagi kesehatan ialah menurunkan darah tinggi, kanker, diare, tipus, memperlancar buang air kecil, dan obat sariawan (Ibu jempol, 2012).

Kandungan per 100 gram adalah energi 12 kalori, niacin $0,2 \mathrm{mg}$ protein $0.7 \mathrm{~g}$, lemak $0.1 \mathrm{~g}$, karbohidrat $2.7 \mathrm{~g}$, vitamin C $8.0 \mathrm{mg}$ dan vitamin B1 $0.3 \mathrm{mg}$, thiamin $0,03 \mathrm{mg}$, kalsium $10 \mathrm{mg}$, fospor $21 \mathrm{mg}$, besi $0.3 \mathrm{mg}$, vitamin A $0 \mathrm{RE}$, riboflavin 0,04 g, (Sumpena, 2001). 
Jurnal Viabel Pertanian Vol. 12 No.2 November 2018

p-ISSN: 1978-5259 e-ISSN: 2527-3345

Copyright@UNISBA Blitar , http://viabel.unisbablitar.ejournal.web.id

Wirianti Masitoh, Palupi Puspitorini \& Jeka Widiatmanta, 2018. Pengaruh Dosis Pupuk

Bioslurry Cair dan Jarak Tanam Terhadap Pertumbuhan dan Hasil Tanaman Mentimun

(Cucumis sativus L.). Journal Viabel Pertanian. (2018), 12 (24) - 32-39

Data produksi tahun 2004 hingga 2010, buah mentimun di Indonesia meningkat sekitar 477,716 ton pada tahun 2004 dan 2005 552,891 ton dan 598,890 ton pada tahun 2006. Tapi produksi mentimun menurun di tahun 2007, 2008 dan 2010 (BPS, 2012).

peningkatan jumlah produksi buah mentimun dapat dilakukan pemupukan yang tepat. Pemupukan adalah memberikan tambahan unsur-unsur hara di tanah untuk memenuhi kebutuhan nutrisi tanaman baik unsur hara makro maupun mikro. Menurut Yunnan Normal University (2010), bioslurry atau limbah biogas adalah pengolahan biogas berbahan campuran kotoran ternak dan air melalui proses tanpa oksigen (anaerob) di dalam ruang yang tertutup.

Bioslurry mengandung bahan organik sebesar $68,59 \%$, C-org $17,87 \%, \mathrm{~N} 1,47 \%, \mathrm{P}$ $0,52 \%, \mathrm{~K} \mathrm{0,38 \%}$, serta C/N 9,09\%.

Untuk meningkatkan produksi mentimun, dilakukan perbaikan teknik budidaya, seperti penggunaan dosis pupuk yang tepat, varietas unggul, serta penerapan jarak tanam yang tepat (Samadi 2002). Pengaturan jarak tanam yang tepat merupakan faktor yang perlu diperhatikan dalam menciptakan kondisi yang sesuai sebagai penunjang pertumbuhan dan hasil tanaman (Guritno \& Sitompul 1995).

Beberapa penelitian tentang jarak tanam, menunjukan bahwa semakin rapat jarak tanam, maka semakin tinggi tanaman tersebut dan secara nyata berpengaruh pada jumlah cabang serta luas daun (Budiastuti, 2000). Menurut Samadi (2002), jarak tanam untuk tanaman mentimun adalah $30 \mathrm{~cm} \times 60 \mathrm{~cm}$.

\section{METODELOGI}

\section{Waktu dan Tempat}

Penelitian ini dilakukan di Desa Banggle, Kecamatan Kanigoro, Kabupaten Blitar. Pelaksanaan dimulai dari bulan Juli sampai dengan bulan Agustus 2018 yang telah memasuki musim kemarau.

\section{Alat dan Bahan}

Alat penelitian ini terdiri dari cangkul, sabit, sprayer, timbangan, meteran, tali rafia, ajir, alat tulis, penggaris dan papan nama. Sedangkan, bahan yang digunakan dalam penelitian ini yaitu benih mentimun dan pupuk bio slurry cair.

\section{Metode Penelitian}

Penelitian menggunakan rancangan acak kelompok yang disusun secara faktorial. Dengan dua faktor yang diulang sebanyak $3 \mathrm{kali}$, faktor pertama ialah dosis pupuk bio slurry cair dengan berbagai dosis yang terdiri atas 3 level yaitu:

$\mathrm{P} 1=$ dosis pupuk organik cair $40 \mathrm{~L} / \mathrm{ha}$

$\mathrm{P} 2=$ dosis pupuk organik cair $80 \mathrm{~L} / \mathrm{ha}$

$\mathrm{P} 3=$ dosis pupuk organik cair $120 \mathrm{~L} / \mathrm{ha}$

Sedangkan faktor kedua yaitu jarak tanam yang terdiri dari 3 level yaitu :

$\mathrm{J} 1=\mathrm{Jarak}$ tanam $60 \mathrm{~cm} \times 30 \mathrm{~cm}$ 
Jurnal Viabel Pertanian Vol. 12 No.2 November 2018

p-ISSN: 1978-5259 e-ISSN: 2527-3345

Copyright@UNISBA Blitar , http://viabel.unisbablitar.ejournal.web.id

Wirianti Masitoh, Palupi Puspitorini \& Jeka Widiatmanta, 2018. Pengaruh Dosis Pupuk

Bioslurry Cair dan Jarak Tanam Terhadap Pertumbuhan dan Hasil Tanaman Mentimun

(Cucumis sativus L.). Journal Viabel Pertanian. (2018), 12 (24) - 32-39

$\mathrm{J} 2=\mathrm{Jarak}$ tanam $60 \mathrm{~cm} \times 40 \mathrm{~cm}$

$\mathrm{J} 3=\mathrm{Jarak}$ tanam $60 \mathrm{~cm} \times 50 \mathrm{~cm}$

$\mathrm{J} 4=\mathrm{Jarak}$ tanam $60 \mathrm{~cm} \times 60 \mathrm{~cm}$

Berdasarkan hasil dari 2 faktor tersebut diperoleh 9 kombinasi perlakuan, perlakuan diulang sebanyak 3 kali dan diperoleh 27 satuan kombinasi. Setiap plot percobaan terdiri 15 tanaman dan diambil 3 tanaman sebagai sampel sehingga tanaman total dalam percobaan 405 tanaman.

\section{Analisis Data}

Analisis data menggunakan sidik ragam (analysis of variance) pada taraf 5\%, apabila terdapat perbedaan di antara perlakuan, maka untuk membandingkan antara dua rata - rata perlakuan dilanjutkan dengan uji Ducan.

\section{Variabel Pengamatan} bobot buah.

Dari penelitian ini yang perlu diamati adalah : diameter batang, luas daun, dan

\section{Hasil Pengamatan}

\section{Diameter Batang}

Berdasarkan hasil analisis ANOVA pada taraf 5\% menunjukkan tidak terdapat interaksi nyata antara perlakuan dosis pupuk bio slurry dan jarak tanam terhadap diameter batang mentimun di semua umur pengamatan (7, 14, 21 dan 28 HST). Perlakuan pupuk bio slurry $(\mathrm{P})$ tidak berpengaruh nyata terhadap diameter batang mentimun di semua umur pengamatan. Namun pada perlakuan jarak tanam $(\mathrm{J})$ memberikan pengaruh nyata terhadap diameter batang mentimun pada umur pengamatan 21 HST. (Lampiran 3) Setelah itu dilakukan Uji DMRT 5\% untuk mengetahui perbedaan antara perlakuan yang terbaik terhadap diameter batang dapat dilihat pada tabel 1 di bawah ini :

Tabel 1. Pengaruh Dosis Pupuk organik (P) dan Jarak Tanam (J) Terhadap Diameter Batang Mentimun Pada Umur 7, 14, 21, 28 HST.

\begin{tabular}{lrrrr}
\hline Perlakuan & \multicolumn{2}{c}{ Diameter Batang } \\
& \multicolumn{2}{c}{ 14 HST } & 21 HST & 28 HST \\
P1 & $0.28 \mathrm{a}$ & $0.61 \mathrm{a}$ & $0.62 \mathrm{a}$ & $0.69 \mathrm{a}$ \\
P2 & $0.28 \mathrm{a}$ & $0.63 \mathrm{a}$ & $0.66 \mathrm{ab}$ & $0.73 \mathrm{a}$ \\
P3 & $0.29 \mathrm{a}$ & $0.63 \mathrm{a}$ & $0.67 \mathrm{~b}$ & $0.74 \mathrm{a}$ \\
& & Jarak Tanam & \\
J1 & $0.26 \mathrm{a}$ & $0.59 \mathrm{a}$ & $0.62 \mathrm{a}$ & $0.68 \mathrm{a}$ \\
J2 & $0.29 \mathrm{a}$ & $0.61 \mathrm{a}$ & $0.64 \mathrm{a}$ & $0.72 \mathrm{ab}$ \\
J3 & $0.29 \mathrm{a}$ & $0.63 \mathrm{a}$ & $0.67 \mathrm{a}$ & $0.74 \mathrm{ab}$ \\
J4 & $0.30 \mathrm{a}$ & $0.66 \mathrm{a}$ & $0.67 \mathrm{a}$ & $0.75 \mathrm{~b}$ \\
\hline
\end{tabular}

Keterangan : Angka-angka yang diikuti dengan huruf yang sama pada baris dan kolom yang sama tidak berbeda nyata pada uji Duncan $(\alpha=0,05)$. 
Jurnal Viabel Pertanian Vol. 12 No.2 November 2018

p-ISSN: 1978-5259 e-ISSN: 2527-3345

Copyright@UNISBA Blitar, http://viabel.unisbablitar.ejournal.web.id

Wirianti Masitoh, Palupi Puspitorini \& Jeka Widiatmanta, 2018. Pengaruh Dosis Pupuk

Bioslurry Cair dan Jarak Tanam Terhadap Pertumbuhan dan Hasil Tanaman Mentimun

(Cucumis sativus L.). Journal Viabel Pertanian. (2018), 12 (24) - 32-39

Dari hasil tabel 1 di atas, ditunjukkan bahwa perlakuan dosis pupuk bio slurry tidak memberikan pengaruh nyata terhadap diameter batang disemua umur pengamatan.

Perlakuan jarak tanam $(\mathrm{J})$ memberikan pengaruh yang nyata terhadap diameter batang pada umur pengamatan 28 HST. Hasil tertinggi ditunjukkan pada perlakuan jarak tanam $\mathrm{J} 4$ sebesar $0,75 \mathrm{~cm}$, dan hasil terendah pada perlakuan jarak tanam $\mathrm{J} 1$ sebesar 0.68 $\mathrm{cm}$. Hal ini dikarenakan dengan penggunaan jarak tanam yang lebar dan jumlah populasi tanaman yang sedikit maka persaingan unsur hara, air dan cahaya semakin menurun. Sejalan dengan pendapat Sarief (1985) bahwa Pengaturan jarak tanam yang sesuai akan menciptakan kondisi faktor lingkungan yang dibutuhkan tanaman tersedia secara merata bagi setiap tanaman dan mengoptimalkan penggunaan faktor lingkungan yang tersedia.

\section{Luas Daun}

Berdasarkan hasil analisis ANOVA pada taraf 5\% menunjukkan tidak terdapat interaksi nyata antara perlakuan dosis pupuk bio slurry dan jarak tanam terhadap diameter batang mentimun di semua umur pengamatan (7, 14, 21 dan 28 HST). Perlakuan pupuk bio slurry $(\mathrm{P})$ tidak memberikan pengaruh nyata terhadap diameter batang mentimun di semua umur pengamatan. Namun pada perlakuan jarak tanam (J) memberikan pengaruh nyata terhadap diameter batang mentimun di umur pengamatan 21 HST. (Lampiran 3) Setelah itu dilakukan Uji DMRT 5\% untuk mengetahui perbedaan antara perlakuan yang terbaik terhadap luas daun dapat dilihat pada tabel 1 di bawah ini :

Tabel 2. Pengaruh Dosis Pupuk organik (P) dan Jarak Tanam (J) Terhadap Luas Daun Mentimun Pada Umur 7, 14, 21, 28 HST.

\begin{tabular}{|c|c|c|c|c|}
\hline \multirow[t]{3}{*}{ Perlakuan } & \multicolumn{4}{|c|}{ Luas Daun } \\
\hline & $7 \mathrm{HST}$ & 14 HST & $21 \mathrm{HST}$ & $28 \mathrm{HST}$ \\
\hline & \multicolumn{3}{|c|}{ Pupuk Bio } & \\
\hline P1 & $16.07 \mathrm{a}$ & $50.56 \mathrm{a}$ & $70.27 \mathrm{a}$ & $85.12 \mathrm{a}$ \\
\hline $\mathrm{P} 2$ & $16.27 \mathrm{a}$ & $52.62 \mathrm{a}$ & $72.66 \mathrm{a}$ & $86.36 \mathrm{a}$ \\
\hline P3 & $16.94 \mathrm{a}$ & $55.73 \mathrm{a}$ & $73.93 \mathrm{a}$ & $86.43 \mathrm{a}$ \\
\hline \multicolumn{5}{|c|}{ Jarak Tanam } \\
\hline $\mathrm{J} 1$ & $13.46 \mathrm{a}$ & $47.77 \mathrm{a}$ & $68.71 \mathrm{a}$ & $79.74 \mathrm{a}$ \\
\hline $\mathrm{J} 2$ & $14.58 \mathrm{a}$ & $50.38 \mathrm{ab}$ & $71.01 \mathrm{a}$ & $84.52 \mathrm{a}$ \\
\hline $\mathrm{J} 3$ & $15.84 \mathrm{a}$ & $53.88 \mathrm{ab}$ & $72.77 \mathrm{ab}$ & $84.68 \mathrm{ab}$ \\
\hline J4 & $21.82 \mathrm{~b}$ & $59.86 \mathrm{~b}$ & $76.67 \mathrm{~b}$ & $94.94 \mathrm{~b}$ \\
\hline
\end{tabular}

Keterangan : Angka-angka yang diikuti dengan huruf yang sama pada baris dan kolom yang sama tidak berbeda nyata pada uji Duncan $(\alpha=0,05)$.

Dari hasil tabel 2 di atas, ditunjukkan bahwa perlakuan dosis pupuk bio slurry tidak memberikan pengaruh nyata terhadap luas daun disemua umur pengamatan.

Pada perlakuan jarak tanam memberikan pengaruh yang nyata terhadap luas daun pada semua umur pengamatan 7, 14, 21, dan 28 HST. Hasil tertinggi ditunjukkan pada perlakuan jarak tanam J4 yaitu 94,94 cm, yang tidak berbeda nyata dengan perlakuan jarak tanam J2 dan J3. Perlakuan jarak tanam J1 menunjukkan rata-rata hasil luas daun terendah yaitu $79,74 \mathrm{~cm}$. Hal ini di duga jarak tanam lebar pertumbuhan daun yang baik memungkinkan tanaman mampu menerima cahaya yang maksimal untuk proses 
Jurnal Viabel Pertanian Vol. 12 No.2 November 2018

p-ISSN: 1978-5259 e-ISSN: 2527-3345

Copyright@UNISBA Blitar , http://viabel.unisbablitar.ejournal.web.id

Wirianti Masitoh, Palupi Puspitorini \& Jeka Widiatmanta, 2018. Pengaruh Dosis Pupuk

Bioslurry Cair dan Jarak Tanam Terhadap Pertumbuhan dan Hasil Tanaman Mentimun

(Cucumis sativus L.). Journal Viabel Pertanian. (2018), 12 (24) - 32-39

pertumbuhan tanaman. Semakin luas daun tanaman maka kemampuan dalam menerima cahaya semakin meningkat.

Sesuai dengan pendapat Patola, E (2005) menyatakan bahwa semakin luas daun tanaman maka penambahan $\mathrm{CO} 2$ untuk berfotosintesis semakin meningkat sehingga mampu meningkatkan pertumbuhan tanaman.

\section{Bobot basah buah}

Berdasarkan hasil analisis sidik ragam (ANOVA) pada taraf 5\% menunjukkan tidak terdapat interaksi yang nyata antara perlakuan dosis pupuk organik dan jarak tanam terhadap bobot basah buah tanaman mentimun. Perlakuan dosis pupuk bio slurry cair (P) tidak berpengaruh nyata terhadap jumlah bobot basah buah tanaman mentimun. Pada perlakuan jarak tanam (J) memberikan pengaruh nyata terhadap bobot basah tanaman mentimun $(\mathrm{kg} / \mathrm{Ha})$. Setelah dilakukan Uji DMRT 5\% untuk mengetahui perbedaan artara perlakuan yang terbaik terhadap jumlah polong total dapat dilihat pada tabel di bawah ini :

Tabel 3. Pengaruh Dosis Pupuk organik (P) dan Jarak Tanam (J) Terhadap Bobot Basah Buah Mentimun.

\begin{tabular}{|c|c|c|}
\hline Perlakuan & $\begin{array}{c}\text { Bobot basah } \\
(\mathrm{g}) / \text { petak }\end{array}$ & $\begin{array}{c}\text { Bobot Basah } \\
\text { (ton)/Ha }\end{array}$ \\
\hline & \multicolumn{2}{|c|}{ Dosis Pupuk Bio Slurry } \\
\hline P1 $\left(40 \mathrm{~L} \mathrm{ha}^{-1}\right)$ & $308.46 a$ & $1.37 \mathrm{a}$ \\
\hline P2 $\left(80 \mathrm{~L} \mathrm{ha}^{-1}\right)$ & $309.68 \mathrm{a}$ & $1.37 \mathrm{a}$ \\
\hline \multirow[t]{2}{*}{ P3 (120 L kg ha $\left.{ }^{-1}\right)$} & $323.06 \mathrm{a}$ & $1.43 \mathrm{a}$ \\
\hline & \multicolumn{2}{|c|}{ Jarak Tanam } \\
\hline J1 (30x60) & $284.97 \mathrm{a}$ & $1.26 \mathrm{a}$ \\
\hline $\mathrm{J} 2(40 \times 60)$ & $292.20 \mathrm{a}$ & $1.29 \mathrm{a}$ \\
\hline J3 ( 50x60) & $331.49 \mathrm{~b}$ & $1.47 \mathrm{~b}$ \\
\hline $\mathrm{J} 4(60 \times 60)$ & $346.27 \mathrm{~b}$ & $1.53 \mathrm{~b}$ \\
\hline
\end{tabular}

Keterangan : Angka-angka yang diikuti dengan huruf yang sama pada baris dan kolom yang sama tidak berbeda nyata pada uji Duncan $(\alpha=0,05)$.

Dari tabel di atas ditunjukkan bahwa perlakuan dosis pupuk bio slurry $(\mathrm{P})$ tidak berpengaruh nyata terhadap jumlah berat basah mentimun. Walaupun tidak berpengaruh nyata namun perlakuan dosis pupuk bio slurry cair $120 \mathrm{~L} \mathrm{ha}^{-1}$ (P3) mempunyai potensi yang lebih baik dari perlakuan dosis pupuk oraganik $40 \mathrm{~L} \mathrm{ha}^{-1}(\mathrm{P} 1)$ dan $80 \mathrm{~L} \mathrm{ha}^{-1}(\mathrm{P} 2)$.

Pada perlakuan jarak tanam (J) berpengaruh nyata terhadap jumlah bobot basah mentimun. Dari perlakuan jarak tanam jarak tanam 60x60 (J4) hasil rata-rata tertinggi yaitu 346.27 g/petak dan 1,53 ton/ha sedangkan pada perlakuan 30x60 (J1) menunjukkan hasil rata-rata terendah yaitu $284.97 \mathrm{~g} /$ petak dan $1,26 \mathrm{~kg} / \mathrm{ha}$. Dari tabel di atas dapat disimpulkan bahwa yang memberikan hasil terbaik dalam variabel bobot basah pada perlakuan jarak tanam yaitu jarak tanam J4 (60x60). Hal ini dikarenakan dengan jarak tanam yang lebar antar tanaman akan menghasilkan bobot buah yang besar karena tidak adanya persaingan unsur hara, air, dan intensitas cahaya yang menyeluruh pada setiap tanaman. 
Jurnal Viabel Pertanian Vol. 12 No.2 November 2018

p-ISSN: 1978-5259 e-ISSN: 2527-3345

Copyright@UNISBA Blitar , http://viabel.unisbablitar.ejournal.web.id

Wirianti Masitoh, Palupi Puspitorini \& Jeka Widiatmanta, 2018. Pengaruh Dosis Pupuk

Bioslurry Cair dan Jarak Tanam Terhadap Pertumbuhan dan Hasil Tanaman Mentimun

(Cucumis sativus L.). Journal Viabel Pertanian. (2018), 12 (24) - 32-39

Pengaturan jarak tanam yang tepat merupakan salah satu faktor yang perlu dilakukan untuk menciptakan kondisi lingkungan yang sesuai dalam menunjang pertumbuhan dan hasil tanaman (Guritno \& Sitompul 1995).

\section{KESIMPULAN}

Berdasarkan hasil penelitian mengenai Pertumbuhan dan Hasil Tanaman Mentimun Pada Berbagai Dosis Pupuk Bio Slurry Cair dan Jarak Tanam Berbeda dapat disimpulkan sebagai berikut :

1. Tidak terdapat interaksi yang nyata pada perlakuan dosis pupuk bio slurry cair dan jarak tanam terhadap pertumbuhan dan hasil tanaman mentimun di semua umur pengamatan.

2. Pemberian dosis pupuk bio slurry cair yang berbeda berpengaruh nyata terhadap variabel diameter batang tanaman mentimun di umur pengamatan 21 HST. Perlakuan dosis pupuk organik yang terbaik yaitu pada perlakuan $120 \mathrm{~L} \mathrm{ha}^{-1}(\mathrm{P} 3)$.

3. Penerapan jarak tanam yang berbeda berpengaruh nyata terhadap variabel diameter batang di umur pengamatan 28 HST, variabel luas daun di semua umur pengamatan, dan variabel bobot total. Hasil terbaik pada perlakuan jarak tanam $60 \times 60 \mathrm{~cm}(\mathrm{~J} 4)$ yang tidak berbeda nyata dengan perlakuan 50x60 cm (J3).

\section{SARAN}

Dari penelitian ini diketahui bahwa dalam budidaya tanaman mentimun disarankan menggunakan jarak tanam 60x60 cm (J4) dikarenakan untuk meminimalisir penggunaan biaya operasional. Selain itu penggunaan jarak tanam yang lebar akan membutuhkan jumlah bibit yang lebih sedikit dengan hasil yang sama dibandingkan dengan penggunaan jarak tanam 50x60 cm (J3) yang membutuhkan jumlah bibit yang lebih banyak.

\section{DAFTAR PUSTAKA}

Agusnani, Aanisah R. 2017. Pengaruh Dosis Pupuk Organik Cair Bio-Slurry dan Waktu Aplikasi Terhadap Pertumbuhan dan Hasil Kubis Bunga (Brassica oleraceae var. botrytis L.). Skripsi. Universitas Lampung. Bandar Lampung. 51 Hal

Agus S. 2013. Pengelolaan dan pemanfaatan Biobio-slurry. https:// www.academia.edu/10389621/Pengelolaan_dan_pemanfaatan_Biobio-slurry. Diakses tanggal 31 Desember 2015

Budiastuti, M. S. 2000. Penggunaan Triokontranol dan jarak tanam pada kacang hijau (Phaseolus radiatus).

BPS.,2012. Produksi Tanaman Sayuran dan Buah-buahan, di indonesia. Badan Pusat Statistik. Jakarta.

Brar, N.S. and D. Singh. 2016. Impact of nitrogenand spacing on the growth and 
Jurnal Viabel Pertanian Vol. 12 No.2 November 2018 p-ISSN: 1978-5259 e-ISSN: 2527-3345

Copyright@UNISBA Blitar , http://viabel.unisbablitar.ejournal.web.id

Wirianti Masitoh, Palupi Puspitorini \& Jeka Widiatmanta, 2018. Pengaruh Dosis Pupuk Bioslurry Cair dan Jarak Tanam Terhadap Pertumbuhan dan Hasil Tanaman Mentimun (Cucumis sativus L.). Journal Viabel Pertanian. (2018), 12 (24) - 32-39

yield of okra[Abelmoschus esculentus (L.) Moench]. MATEC Web of Conferences 57: 1-7

Gomies L., Rehatta H., dan Nandisa J. 2012. Pengaruh Pupuk Organik Cair RII Terhadap Pertumbuhan Dan Produksi Tanaman Kubis Bunga (Brassicaoleraceae var. botrytis L.). Agrologia (1) $1: 13-20$

Guritno, \& S. M. Sitompul. 1995. Analisis Pertumbuhan Tanaman. Gajah Mada, Yogyakarta.

Hartanto, Y \& C.H. Putri. 2013. Pedoman Pengguna \& Pengawas Pengelolaan dan Pemanfaatan Bio-slurry. TimBiogas Rumah (Biru), Yayasan Rumah Energi. Jakarta.

Ibujempol. 2012. Khasiat Manfaat Mentimun Timun Ketimun. http://www. ibujempol. com/khasiat manfaat-mentimun-timun-ketimun/.

Imdad, H. P dan Nawangsih, AA. 2001. Sayuran Jepang Edisi ke-3. Jakarta: PT. Penebar Swadaya. 76-78 hal

J. Suprapto.(1992)., Teknik Sampling Untuk Survey dan Eksperimen, Rinika Cipta

Kariada, I.K, M. Sunantara, dan I.B. Aribawa. 2003. Pengaruh Beberapa Dosis Pupuk Urea dan Jarak Tanam terhadap Pertumbuhan dan Hasil Padi Gogo Di Lahan Kering. Balai Pengkajian Teknologi Pertanian Bali. Denpasar.

Lingga, P. 1994. Petunjuk Penggunaan Pupuk. Penebar swadaya. Jakarta. 163 hlm.

Mikail, B. dan A. Candra. 2011. Manfaat Tersembunyi Mentimun. http://health. kompas.com/read/2011/08/17/10402067/12.Manfaat.Tersembunyi. Mentimun.Kompas.

Patola, E. 2008.Analisis Pengaruh Dosis Pupuk Urea dan Jarak Tanam terhadap Produktivitas Jagung Hibrida P-21 (Zea mays L.).J Inovasi Pertanian $7(1): 51-65$.

Rubatzky, V. E. 1999. Sayuran Dunia 3: Institut Teknologi Bandung. Bandung.

Rukmana, R. 1994. Budidaya Mentimun. Kanisius, Yokyakarta. 67 hlm.

Samadi, B. 2002. Teknik Budidaya Mentimun Hibrida. Kanisius. Yogyakarta.

Sarif, E. S. 1985. Kesuburan dan Pemupukan Tanah Pertanian. Penerbit Pustaka Buana, Bandung.

Septiyaning, I. 2011. Kemarau Hasil Panen Mentimun Menyusut. http://www.solopos.com/2011/karanganyar/kemarau-hasil-panen 
Jurnal Viabel Pertanian Vol. 12 No.2 November 2018 p-ISSN: 1978-5259 e-ISSN: 2527-3345

Copyright@UNISBA Blitar , http://viabel.unisbablitar.ejournal.web.id

Wirianti Masitoh, Palupi Puspitorini \& Jeka Widiatmanta, 2018. Pengaruh Dosis Pupuk Bioslurry Cair dan Jarak Tanam Terhadap Pertumbuhan dan Hasil Tanaman Mentimun (Cucumis sativus L.). Journal Viabel Pertanian. (2018), 12 (24) - 32-39

mentimunmenyusut116147.SoloPos. Solo.

Sharma, O.P. 2002. Plant Taxonomy. New Delhi: Tata McGraw-Hill Publishing Company Limited. 482 page

Simarmata, T. 2005. Aplikasi pupuk biologis dan pupuk organik untuk Meningkatkan kesehatan tanah dan hasil tanaman tomat (Lycopersicon esculentum Mill.) pada Inceptisols di Jatinangor. Jurnal Agroland. 12(3): 261-266.

Soetejo, M.M dan A.G Kartasapoetra. 1988. Pupuk dan Cara Pemupukan. PT. Bima Aksara, Jakarta. $223 \mathrm{hlm}$.

Suhadi, M. 1980. Meningkatkan Produktivitas Melalui Pupuk Daun. Trubus $131(9): 36-38$

Sumpena, U. 2001. Budidaya Mentimun Intensif. Penebar Swadaya. Jakarta. 80 $\mathrm{Hlm}$

Sumpena, U. 2008. Budidaya Mentimun Intensif, dengan Mulsa, secara Tumpang Gilir. Jakarta: Penebar Swadaya. 80 hal

Sunarjono, H. 2005. Bertanam 30 Jenis Sayuran. Jakarta: Penebar Swadaya. 183 hal.

Tim Biogas Rumah (Tim Biru). 2013. Pedoman dan Pengguna Pengawas Pengelolaan dan Pemanfaatan Bio-slurry. Program BIRU Kerjasama Indonesia - Belanda. Jakarta. $40 \mathrm{Hal}$

Untung, K. 1993. Pengantar Pengelolaan Hama Terpadu. Gadjah Mada Press. Yogyakarta.

Wachjar, A dan Kadarisman, L. 2007. PengaruhKombinasi Pupuk Organik Cair dan Pupuk Anorganik serta Frekuensi Aplikasinya terhadap Pertumbuhan Tanaman Kakao (Theobroma cacao L.). Belum Menghasilkan. Jurnal. Agro. No 35(3): 212 - 216.

Warintek. 2006. Mentimun. Diakses dari http://warintek.progressio.or.id.

Wijoyo, P.M. 2012. Budi Daya Mentimun Yang Lebih Menguntungkan. Pustaka AgroIndonesia. Jakarta.

Yunna Normal University. 2010. Tentang Bio-Slurry. http://www.biru.or.id/indext.php/bio-bio-slurry/. Diakses tanggal 1 November 2015

Zulkarnain. 2013. Budidaya Sayuran Tropis: Bumi Aksara. Jakarta. 